\title{
Development of emergency response plans for community water systems
}

\author{
U Jack ${ }^{1 *}$, Philip de Souza' and N Kalebaila ${ }^{2}$ \\ 'Emanti Management, PO Box 1264, Stellenbosch, 7599, South Africa \\ ${ }^{2}$ Water Research Commission, Private Bag X03, Gezina, 0031, South Africa
}

\begin{abstract}
All water services systems, irrespective of size, location etc., should have emergency response plans (ERPs) to guide officials, stakeholders and consumers through emergencies, as part of managing risks in the water supply system. Emergencies in the water supply system may result from, among other causes, natural disasters, equipment failure, human error and intentional acts (e.g. vandalism). Simply put, an ERP prepares the organisation for emergencies and gives specific instructions about what to do if there is an emergency situation that may affect the water system. To assist water services institutions (WSIs), the Water Research Commission project 'Water Safety and Security: Emergency Response Plans' aimed to develop a generic ERP guide for community water systems (CWS). A CWS in this study was defined as a potable water service provided to a rural community where municipal constraints exist and there is either 'no supply' or water is provided up to a communal standpipe. Emergencies considered in this study include (i) unavailability of water or (ii) excess of water (e.g. flood) and (iii) water quality or pollution/contamination. CWS in 3 provinces in South Africa (Eastern Cape, KwaZulu-Natal and Northern Cape), were visited to (i) identify the water service delivery status, methods and possible shared threats/vulnerabilities and risks (ii) identify water services challenges experienced by these communities (iii) ascertain who owns and who is responsible for water services (e.g. whether these communities are serviced by municipalities or by local chiefs and/or trusts) and (iv) investigate whether the systems have been documented and evaluated. Following site visits, an ERP guideline document with associated templates will be developed and workshopped with the selected communities, which will include: (i) conditions identified as emergencies, (ii) communication procedures/protocol/chain of command, and (iii) procedures detailing how to attend to the specified emergencies.
\end{abstract}

Keywords: potable; supply; emergency; public health

\section{INTRODUCTION}

All water service systems, irrespective of size, location, etc., should have emergency response plans (ERPs) that are a key component of water safety planning. The purpose of emergency response plans is to guide officials, stakeholders and consumers through emergencies as part of managing risks in the water supply system. Emergencies in the water supply system may result from, among other causes, natural disasters, inappropriate or poor design and planning, system neglect or poor maintenance, poor operations and intentional acts (e.g. vandalism). Simply put, an ERP prepares the organisation for emergencies and gives specific instructions about what to do if there is an emergency situation that may affect the water system.

Managers and technical staff need to understand what plans and budgets should be developed and implemented to successfully operate and maintain water services. A wide variety of topics need to be addressed including, for example, the need to expand the water treatment system, a desire to improve the efficiency of the treatment process or a desire to improve working conditions/water safety. ERPs should have clear aims and objectives, should address how to deal with changing circumstances (issues and risks arising) and should specify what resources (people, money, time) will be needed to implement

This paper was originally presented at the 2014 Water Institute of Southern Africa (WISA) Biennial Conference, Mbombela, 25-29 May 2014

* To whom all correspondence should be addressed

ธ +2721880 2932; fax: +27218802931

e-mail: unathij@emanti.co.za the plan. Finally, mechanisms should be established to periodically review and, where necessary, revise plans and budgets to reflect changing circumstances.

\section{Community water systems}

The aim of this study is to assist communities to identify threats and vulnerabilities in the water supply system that may lead to emergencies. Emergencies considered in this study include (i) unavailability of water, (ii) excess of water (as in a flood situation) and (iii) water quality or pollution/contamination.

Community water systems (CWS) in this study are systems that are mostly found in rural communities with informal supply systems (meaning it is a system with some but not all of the elements of a standard water supply system that include source, treatment, distribution, network up to the point of use).

For the purpose of this project, a CWS is defined as: (i) a potable water service provided in a rural area, (ii) where there is little municipal involvement, and (iii) where there is either 'no supply' or water is provided up to a communal standpipe. Note: The size of the serviced area and associated population are not considered as deciding factors.

The systems focused on in this study are therefore characterised by one or a combination of the following:

- Water is pumped from a source or the system receives bulk water that is pumped to a reservoir, distributed to the network and to a communal standpipe within or further than $200 \mathrm{~m}$ from a dwelling.

- Water received is obtained directly from a source and not treated (e.g. a river, a well, a spring, a borehole), which is considered 'no supply'. 
- Water is collected from a communal reservoir where rainwater harvesting is practised or individual rainwater is collected into storage tanks.

- Water is transported by tankers to a communal reservoir or directly to consumers.

\section{Emergency response planning}

From the literature review conducted, it was noted that although each country has its own methodology for dealing with emergencies, there are similar components/elements for developing and implementing ERPs. The literature reviewed on development and implementation of ERPs include US EPA (2004), US EPA (2006), RCAP (2005), Washington State Department of Health (2011), EMA (2004), and WHO (2013). Considering South African policies, legislation, frameworks (DWAF, 2003; RSA, 1998) and international guidelines, the approach considered is indicated in Table 1. This approach also considers the water safety planning approach/steps that most water services institutions are familiar with (Thompson and Majam, 2009; Jack and de Souza, 2013). This should facilitate more rapid uptake of ERPs. In this approach, emergency response planning is a component of a WSP as shown in the table below, whilst in other countries these are all ERP core elements.

\section{METHODOLOGY}

\section{Selected sites}

Site visits were conducted in 4 municipalities in 3 provinces: Joe Gqabi and Chris Hani District Municipalities in the Eastern Cape, Newcastle Local Municipality in KwaZulu-Natal, and Hantam Local Municipality in the Northern Cape.

The purpose of conducting these site visits was to:

- Determine the current status of the selected systems

- Identify water service delivery methods and possible shared threats/vulnerabilities and risks
- Identify water services challenges experienced by the selected communities

- Ascertain who owns and who is responsible for water services (e.g. whether these communities are serviced by municipalities or by local chiefs and/or trusts)

- Investigate whether the systems have been documented and evaluated

\section{Site visit methodology}

A meeting was held with each of the selected municipalities where the project was introduced. At this meeting, the appropriate systems were selected and discussed including their status, delivery methods, ownership, threats/vulnerabilities and risks. The method of determining who should be involved, both internally and externally to the municipality, and form part of the ERP team was discussed. Water quality monitoring methods practised (if available) and the need for monitoring were also discussed.

A CWS tool was developed in order to facilitate the process, to determine the status of the water services, and to present the results in a more structured and understandable way. The tool has 8 categories with 5 key statements per category. The tool components are shown in Fig. 1.

The user has to respond with one of the available options, where each option was allocated a score (Fig. 1). Once the tool has been completed, a spider diagram is automatically generated. This spider diagram highlights key areas of vulnerability, threat and risk within the CWS (Fig. 2).

\section{RESULTS AND DISCUSSION}

Each CWS was documented and described. On-site observations were recorded and supported with photos. Threats, vulnerabilities and risks were identified and recorded. Two examples of CWS case studies are presented below. The diagrams documenting each CWS indicate that the systems are generally quite simple.

\begin{tabular}{|c|c|}
\hline \multicolumn{2}{|r|}{$\begin{array}{l}\text { TABLE } 1 \\
\text { ERP project core elements }\end{array}$} \\
\hline ERP elements & Considerations \\
\hline 1 Identify ERP team & Who needs to be, should be and wants to be involved? \\
\hline 2 Document and describe the CWS & Proper documentation of the CWS with drawings, maps, photos \\
\hline $\begin{array}{l}3 \text { Identify types of disasters or emergencies to } \\
\text { be addressed }\end{array}$ & $\begin{array}{l}\text { What are current and possible threats, vulnerabilities, risks and expected disasters associ- } \\
\text { ated with the system? }\end{array}$ \\
\hline 4 Analyse the possible events/challenges & $\begin{array}{l}\text { What is the likelihood that the threat, risk or emergency will happen and what are the likely } \\
\text { consequences? }\end{array}$ \\
\hline $5 \quad$ Plan for anticipated emergencies & $\begin{array}{l}\text { How do we get to where we want to be? } \\
\text { - } \quad \text { Procedures (step by step, how to react) } \\
\text { - } \quad \text { Communication protocol } \\
\text { - } \quad \text { Assign responsibilities } \\
\text { - } \quad \text { Identify alert levels } \\
\text { - } \quad \text { Management of resources (equipment, people, services) } \\
\text { - Infrastructure protection }\end{array}$ \\
\hline $6 \quad$ Sampling and monitoring & $\begin{array}{l}\text { What water quality records and relevant management records do we need? How will they } \\
\text { assist us in planning? }\end{array}$ \\
\hline $\begin{array}{l}7 \text { Document and review all aspects of ERP } \\
\text { implementation }\end{array}$ & $\begin{array}{l}\text { What do we need to do to ensure that our systems work well and are continuously } \\
\text { improved? }\end{array}$ \\
\hline
\end{tabular}




\begin{tabular}{|c|c|}
\hline \multicolumn{2}{|c|}{ Scoring Rules } \\
\hline Strongly disagree or don't know & 0 \\
\hline Disagree & 1 \\
\hline Neutral & 2 \\
\hline Agree & 3 \\
\hline Strongly agree & 4 \\
\hline Not Applicable & 4 \\
\hline
\end{tabular}

\begin{tabular}{|c|l|c|}
\hline \multicolumn{3}{|c|}{ 1. Emergency Response Plans } \\
\hline 1.1 & $\begin{array}{l}\text { There is an ERP available and implemented } \\
\text { with assigned roles and responsibilities }\end{array}$ & $\mathbf{0}$ \\
\hline 1.2 & $\begin{array}{l}\text { There is an ERP leader responsible for oo- } \\
\text { ordinating any reported emergency with } \\
\text { relevant parties }\end{array}$ & $\mathbf{0}$ \\
\hline 1.3 & $\begin{array}{l}\text { The ERP addresses the communication } \\
\text { protocol in case of emergency }\end{array}$ & $\mathbf{0}$ \\
\hline 1.4 & $\begin{array}{l}\text { The ERP has procedures and protocols on } \\
\text { what to do in case of specific emergency }\end{array}$ & $\mathbf{0}$ \\
\hline 1.5 & $\begin{array}{l}\text { The ERP is regularly updated to check } \\
\text { relevancy and ensure all potential } \\
\text { threatsivulnerabilities are addressed }\end{array}$ & $\mathbf{0}$ \\
\hline \hline \multicolumn{2}{|c}{ 4. Storage }
\end{tabular}

\begin{tabular}{|c|l|c|}
\hline \multicolumn{3}{|c|}{ 2. Source (Rav v ater) } \\
\hline 2.1 & $\begin{array}{l}\text { The water source is safe from contamination } \\
\text { by communities (recreational use, surface run- } \\
\text { off of faecal matter, infiltrating pit lattrines, etc.) }\end{array}$ & $\mathbf{3}$ \\
\hline 2.2 & $\begin{array}{l}\text { The w ater source is safe from contamination } \\
\text { by light industries, agriculture and livestock }\end{array}$ & $\mathbf{0}$ \\
\hline 2.3 & $\begin{array}{l}\text { The quantity of water available from the } \\
\text { source is sufficient for community needs }\end{array}$ & $\mathbf{4}$ \\
\hline 2.5 & $\begin{array}{l}\text { There is an alternative raw water source in } \\
\text { case the primary source is contaminated or } \\
\text { water is unavailable }\end{array}$ & $\mathbf{0}$ \\
\hline $\begin{array}{l}\text { There is no littering, solid w aste, dead animals } \\
\text { found close to the source or dumped into the } \\
\text { source }\end{array}$ & $\mathbf{0}$ \\
\hline
\end{tabular}

\begin{tabular}{|c|c|c|}
\hline 3.1 & $\begin{array}{l}\text { The treatment facility is secured against } \\
\text { theft and vandalism }\end{array}$ & 0 \\
\hline 3.2 & $\begin{array}{l}\text { The treatment facility is appropriate for the } \\
\text { quantity and quality requirements }\end{array}$ & 0 \\
\hline 3.3 & $\begin{array}{l}\text { Treatment facility has sufficient } \\
\text { chemicalsimaterials required for operations } \\
\text { including standbylspare equipment }\end{array}$ & 4 \\
\hline 3.4 & $\begin{array}{l}\text { The treatment facility has a responsible } \\
\text { person with appropriate skills for treatment } \\
\text { requirements }\end{array}$ & 3 \\
\hline 3.5 & $\begin{array}{l}\text { An appropriate operating procedure and } \\
\text { maintenance schedule is available and } \\
\text { implemented }\end{array}$ & 1 \\
\hline
\end{tabular}

\begin{tabular}{|c|l|c|}
\hline \hline \multicolumn{3}{|c|}{ 4. Storage } \\
\hline 4.1 & $\begin{array}{l}\text { The storage capacity is sulficient to meet } \\
\text { community needs }\end{array}$ & 4 \\
\hline 4.2 & $\begin{array}{l}\text { Communal storage facility is not easily } \\
\text { accessible to the public (e. g. closed tops) }\end{array}$ & $\mathbf{0}$ \\
\hline 4.3 & $\begin{array}{l}\text { The communal storage facility is cleaned and } \\
\text { maintained on a regular basis (e.g. at least } \\
\text { annually) }\end{array}$ & $\mathbf{1}$ \\
\hline 4.5 & $\begin{array}{l}\text { The water does notremain stagnant within the } \\
\text { communal storage facility for extended } \\
\text { periods of time. }\end{array}$ & $\mathbf{3}$ \\
\hline $\begin{array}{l}\text { Household storage is cleaned on a regular } \\
\text { basis }\end{array}$ & 2 \\
\hline \hline
\end{tabular}

\begin{tabular}{|c|l|c|}
\hline \multicolumn{2}{|c|}{5 . Pipes } \\
\hline 5.1 & $\begin{array}{l}\text { There is no evidence of pipe leakagelbursts } \\
\text { within the pipe network }\end{array}$ & $\mathbf{3}$ \\
\hline 5.2 & $\begin{array}{l}\text { Pipe infrastructure is not aged such that it } \\
\text { result in contamination and water loss }\end{array}$ & $\mathbf{3}$ \\
\hline 5.3 & $\begin{array}{l}\text { Pipes are not vulnerable to theft and } \\
\text { uandalimleg illegal connections }\end{array}$ & $\mathbf{3}$ \\
\hline
\end{tabular}

\begin{tabular}{|c|c|c|}
\hline \multicolumn{3}{|c|}{ 6. Water Quality } \\
\hline 6.1 & $\begin{array}{l}\text { The drinking w ater provided is fit for drinking } \\
\text { purposes }\end{array}$ & 0 \\
\hline 6.2 & 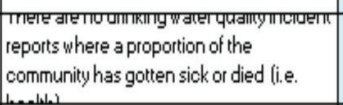 & 0 \\
\hline 6.3 & $\begin{array}{l}\text { The drinking water does not tasteismell } \\
\text { offensively }\end{array}$ & 3 \\
\hline 6.4 & $\begin{array}{l}\text { The drinking water does not look muddy' } \\
\text { unclear }\end{array}$ & 3 \\
\hline 6.5 & $\begin{array}{l}\text { Alternative home treatment methods are } \\
\text { available to improve drinking water quality } \\
\text { at point of use }\end{array}$ & 2 \\
\hline
\end{tabular}

\begin{tabular}{|c|l|c|}
\hline \hline \multicolumn{2}{|c|}{ 7. Water Quantity } \\
\hline 7.1 & $\begin{array}{l}\text { The drinking water provided is sufficient for } \\
\text { community needs }\end{array}$ & $\mathbf{4}$ \\
\hline 7.2 & $\begin{array}{l}\text { There is no big seasonal variation in water use } \\
\text { (i.e. peak demands can be met) }\end{array}$ & $\mathbf{3}$ \\
\hline 7.3 & $\begin{array}{l}\text { The community is not expanding (i.e. w ater } \\
\text { use assumed constant) }\end{array}$ & $\mathbf{3}$ \\
\hline 7.4 & $\begin{array}{l}\text { There is no intermittent supply of piped w ater } \\
\text { such that consumers switch to source of lower } \\
\text { quality or experience unequal provision of } \\
\text { supply. }\end{array}$ & $\mathbf{3}$ \\
\hline 7.5 & $\begin{array}{l}\text { The community does not experience water } \\
\text { pressure problems (e.g. no flowipartial flow } \\
\text { less than 10 litresiminute) }\end{array}$ & $\mathbf{3}$ \\
\hline \hline
\end{tabular}

\begin{tabular}{|c|l|c||}
\hline \multicolumn{3}{|c|}{ 8. Community Arareness } \\
\hline 8.1 & $\begin{array}{l}\text { The community is aw are of what to do in case } \\
\text { of emergency }\end{array}$ & $\mathbf{3}$ \\
\hline 8.2 & $\begin{array}{l}\text { Community aw areness programmes on w ater } \\
\text { issues are carried out }\end{array}$ & $\mathbf{0}$ \\
\hline 8.3 & $\begin{array}{l}\text { Community is informed when there is drinking } \\
\text { water contamination (i.e. water quality issues) }\end{array}$ & $\mathbf{0}$ \\
\hline 8.4 & $\begin{array}{l}\text { Community is informed when there are water } \\
\text { shortages (i.e. water quantity issues) }\end{array}$ & $\mathbf{4}$ \\
\hline 8.5 & $\begin{array}{l}\text { Recommendations are provided to } \\
\text { communities to deal with specific issues }\end{array}$ & $\mathbf{0}$ \\
\hline
\end{tabular}

Figure 1

CWS status tool 


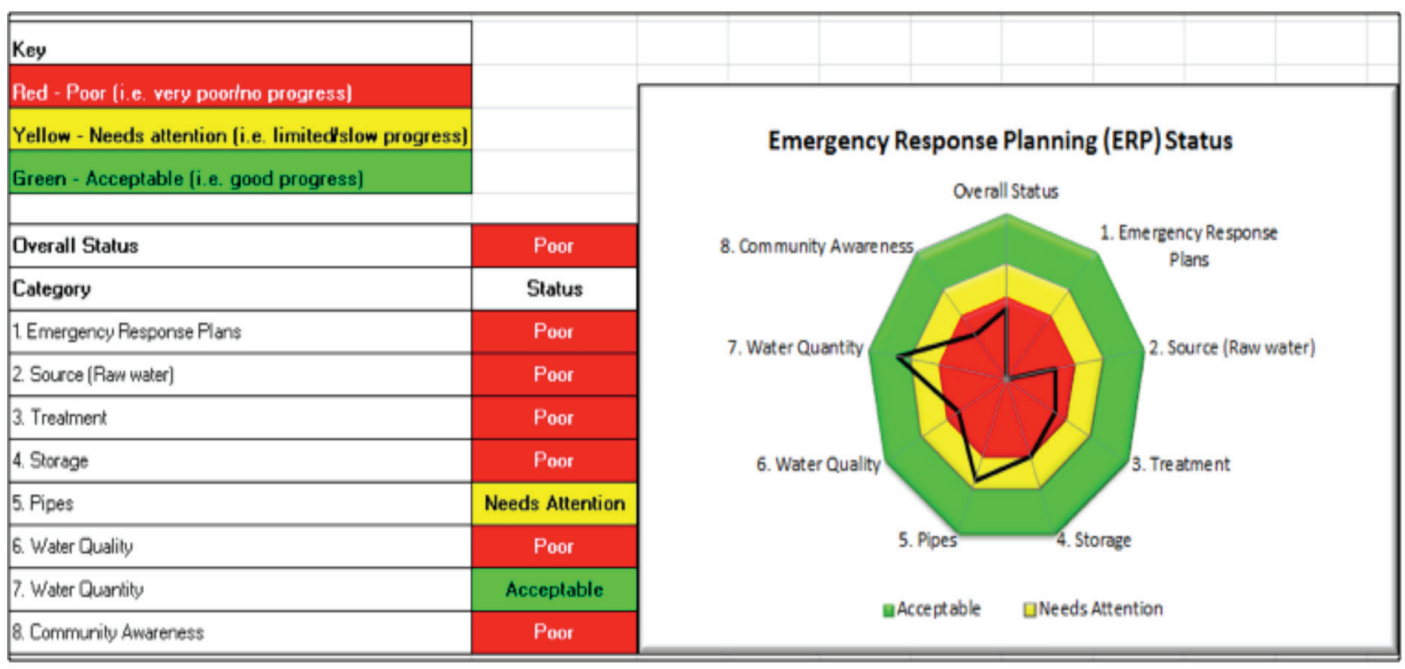

Figure 2

CWS status tool report (spider chart)

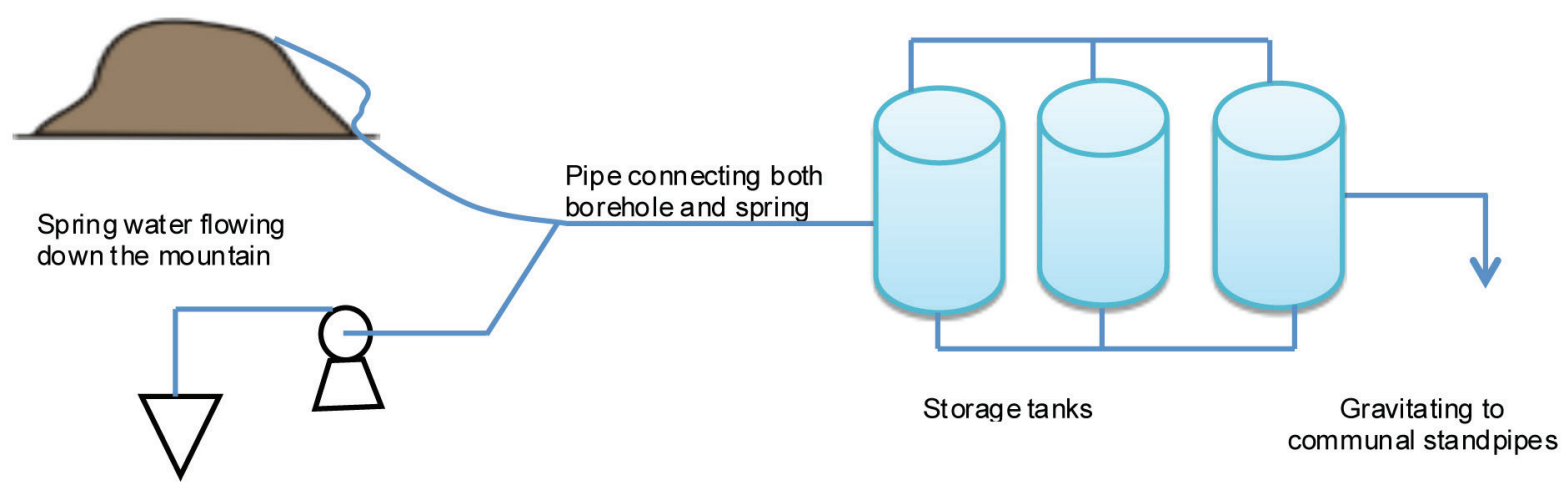

Figure 3

Case Study 1 schematic representation

\section{Case Study 1}

\section{Documenting and describing the system}

Case Study 1 CWS has two raw water sources, a mountain spring and a borehole (Fig. 3). The borehole is only used when the spring is running dry. The water table is considered to be very high such that water availability is not a challenge in this area. Water from the spring gravitates to 3 storage tanks. The borehole water is pumped to the same 3 storage tanks, using a diesel pump.

\section{On-site observations}

On-site observations were recorded and supported with photos (Fig. 4).

- One of the 3 storage tanks is broken and seems not to be in use. This has been noted not to affect the reservoir capacity versus water demand.

- The storage tanks are enclosed with lids.

- The storage tanks are easily accessible to the public.

- The tanks are linked together and there are pipes connected to an overflow weir.
- There is no clear indication where the overflow from the storage tanks discharges to.

- The pump house is located close to a wetland and pit latrines.

- There is evidence of littering around the wetland.

- There is evidence of rainwater harvesting by some residents.

\section{Threats, vulnerabilities and risks}

Threats, vulnerabilities and risks were identified and recorded.

- Due to the high level of the water table, there is always water in the pump house which may damage the equipment.

- Groundwater may be contaminated by pit latrines if not protected.

- Groundwater may be contaminated by the wetland.

- Distribution pipes are exposed above the ground due to erosion.

\section{Case Study 2}

\section{Documenting and describing the system}

Case Study 2 CWS is a tanker service which collects water from the water treatment works and delivers it to storage tanks in the 
area. The tankers are owned by the municipality. Some areas do not have storage tanks and the community uses drums to store water from the tankers. Water is transported weekly to the storage tanks (Fig. 5).

\section{On-site observations}

On-site observations were recorded and supported with photos (Fig. 6).

- Municipal plastic tanks are a bluish colour that distinguishes them from the usual green tanks.

- Some storage tank stands are cracked.

- Some of the storage tank lids do not close properly.

- There is evidence of water spillage around the storage tanks.

- Rainwater harvesting is practised by many of the households in the area.

\section{Threats, vulnerabilities and risks}

Threats, vulnerabilities and risks were identified and recorded.

- The cracked stands may not be stable enough to carry the weight of the storage tanks.

- Storage tanks that are not properly closed may be vulnerable to pollution.

- Some of the drums that are used to collect water are not hygienic (e.g. enclosed with rusted zinc).

\section{CONCLUSIONS}

Considering the observations from the sites visited in all three provinces, the following recommendations can be made.

Source protection (fencing) in some instances may not be effective. Other methods of ensuring safe drinking water should
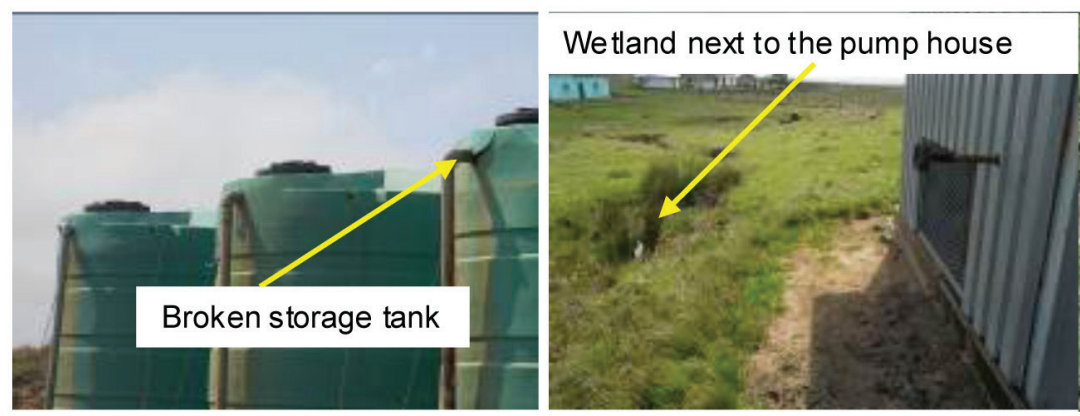

Figure 4

Case Study 1 on-site observation issues noted

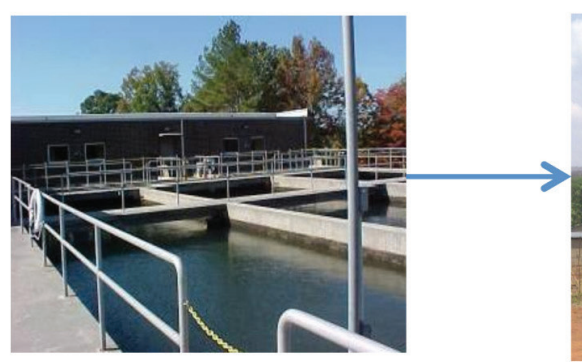

Water treatment works

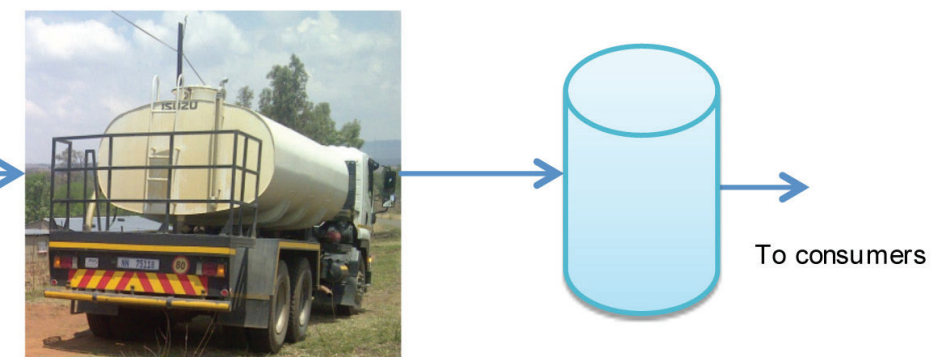

Water transported by tanker

Storage tanks

Figure 5

Case Study 2 water supply mechanism
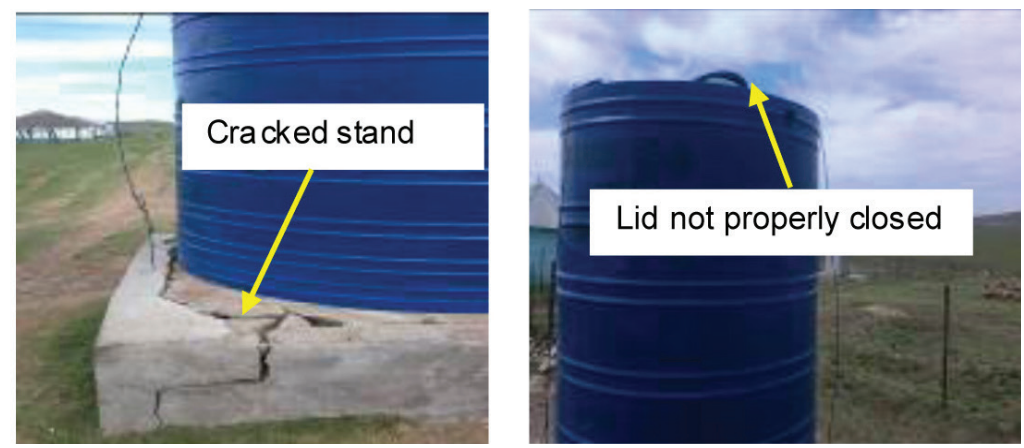

Figure 6

Case Study 2 on-site observation issues noted 
therefore be considered. Improved community awareness is required. Focus items include water quality, water conservation and household treatment methods. Community involvement may result in more responsibility being taken by the community. Water quality monitoring is crucial to understanding if the water is safe or if additional treatment is required. Development of operations and maintenance programmes is vital.

A guideline document with associated templates for developing and implementing an ERP will be developed, that will include conditions identified as emergencies, procedures on how to attend to the specified emergencies, and templates for certain procedures/protocol/chain of command.

\section{ACKNOWLEDGMENTS}

The Water Research Commission is thanked for its financial support for this work.

\section{REFERENCES}

EMA (EMERGENCY MANAGEMENT AUSTRALIA) (2004) Emergency Risk Management Applications Guide Manual 5. URL: http://www.em.gov.au/Documents/Manual\%20 05-ApplicationsGuide.pdf (Accessed 28 November 2013).

JACK U and DE SOUZA P (2013) Guidelines on using the refined and translated web-enabled Water Safety Plan tool. WRC Report No TT581/13. Water Research Commission, Pretoria.
RCAP (RURAL COMMUNITY ASSISTANCE PARTNERSHIP) (2005) Emergency response planning guide for public drinking water. URL: http://www2.epa.gov/sites/production/files/documents/ erp_rcap.pdf (Accessed 13 June 2013).

RSA (REPUBLIC OF SOUTH AFRICA) (1998) National Water Act (Act No 36 of 1998). Government Printer, Pretoria.

THOMPSON P and MAJAM S (2009) The development of a generic water safety plan for small community water supply. WRC Report No. TT 415/09. Water Research Commission, Pretoria.

US EPA (UNITED STATES ENVIRONMENTAL PROTECTION AGENCY) (2004) Emergency response plan guidance for small and medium community water systems to comply with the Public Health Security and Bioterrorism Preparedness and Response Act of 2002. URL: http://www.epa.gov/safewater/watersecurity/pubs/ small_medium_ERP_guidance040704.pdf (Accessed 3 March 2013).

US EPA (UNITED STATES ENVIRONMENTAL PROTECTION AGENCY) (2006) A water security handbook: Planning for and responding to drinking water contamination threats and incidents. URL: http://www.epa.gov/watersecurity/pubs/water_security_ handbook_rptb.pdf (Accessed 13 June 2013).

WASHINGTON STATE DEPARTMENT OF HEALTH (2011) Water system security and emergency response planning. Washington. URL: http://www.doh.wa.gov/Portals/1/Documents/Pubs/331-199. pdf (Accessed 25 July 2013).

WHO (WORLD HEALTH ORGANISATION) (2013) Technical notes on drinking-water, sanitation and hygiene in emergencies. Emergency treatment of drinking water at the point of use. Geneva. URL: http://www.who.int/water_sanitation_health/publications/2011/WHO_TN_05_Emergency_treatment_of_drinking_ water_at_the_point_of_use.pdf (accessed 19 February 2013). 